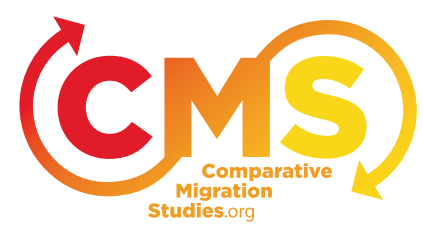

\title{
The Effects of Islam, Religiosity, and Socialization on Muslim-Canadian Opinions about Same-Sex Marriage
}

\author{
Christopher Cochrane
}

\author{
CMS 1 (1): 147-178 \\ DOI: 10.5117/CMS2013.1.COCH
}

\begin{abstract}
Critics of Islam often frame anti-Islamic positions as a defense of tolerance against intolerance, and of equality against inequality. Islam, for this perspective, poses challenges for the ideological integration of Muslim immigrants in Western societies. This paper examines Canadian Muslims' opinions about same-sex marriage. The analysis suggests that Canadian Muslims, as a group, do have distinctively negative opinions about same-sex marriage, but that there is substantial and systematic variation in opinions about this issue within the Muslim-Canadian community. Indeed, it is religiosity in general, rather than Islam in particular, that generates negative opinions about gay marriage. Exposure to the Canadian context, and especially postsecondary education, largely undoes the distinctiveness of Canadian Muslims' opinions about this issue.
\end{abstract}

Keywords: Islam, Muslims, Immigration, Public Opinion, Same-Sex Marriage

\section{Introduction}

In January 2007, the town of Hérouxville, Québec, Canada drafted a series of resolutions aimed at prospective immigrants. The most controversial resolution prohibited the stoning of women in public. "Nous considérons que les hommes et les femmes sont égaux et ont la même valeur," the document proclaims, reaffirming the community's basic commitment to the fundamental rights of women, including their right to walk unaccompanied in public, attend school, and operate a vehicle (Municipalité de Hérouxville, 2010). The anti-Muslim sentiment that inspired these resolutions was 
certainly unusual in its candor (Bouchard and Taylor, 2008). But it was not unusual in its form. Critics of Islam in Canada and across the Western world often frame anti-Islamic positions as a defense of tolerance against intolerance, and of equality against inequality (Akkerman, 2005, 2010; Betz and Meret, 2009; Ehrkamp, 2010; Mepschen, Duyvendak and Tonkens, 2010; Razak, 2008; Shachar, 2000). Acceptance of sexual diversity in particular, which is a very recent phenomenon in Western countries, is a core tenet of a new "cultural citizenship" in democratic societies that is often invoked against Muslims and against Islam (Mepschen, Duyvendak and Tonkens, 2010; see also Fassin, 2010).

Most of the research on Muslim immigration is focused on the European context, where levels of Muslim immigration, and the political backlash against it, are far more extensive than in the Canadian case (Adida, Laitin and Valfort, 2010; Bleich, 2003, 2009; Bevelander and Otterbeck, 2010; Connor, 2010; Ehrkamp, 2010; Fekete, 2008; Fetzer and Soper, 2003; Scheepers, Gijsberts and Coenders, 2002; Semyonov, Raijman and Gorodzeisky, 2006; Shadid, 1991; Sniderman et al., 2000; Strabac and Listhaug, 2008; Zolberg and Litt Woon, 1999). Debates about Muslim immigration, however, are increasingly important to Canada. The size of the Canadian Muslim population more than doubled between the 1991 and 2001 censuses, and this growth has continued apace. Worldwide population and migration patterns mean that Muslims will comprise an increasing share of immigrants to Canada for the next several years. By 2030, the number of Muslims in Canada is estimated to triple, from 940 thousand to 2.7 million, or 6.6 percent of the national population (Pew Research Center, 2011).

Canada has the second highest per-capita immigration rate in the OECD, and the proportion of foreign-born (and non-British) citizens has never fallen below 13 percent in the country's 144 year history (Chui, Tran and Maheux, 2007). Indeed, multiculturalism is so entrenched in Canada that many consider it a signature characteristic of the country's political culture (Eliadis, 2007). In the 2006 World Values Survey, less than 3 percent of Canadians indicated that they did not want "people of a different race" as neighbors; less than 2.5 percent said the same thing about "immigrants," and fewer still said the same about "people of a different religion" (European Values Study Group and World Values Survey Association, 2010). Even so, Muslim immigrants in particular are often singled out for the supposed incompatibility of Islam with core liberal values, especially regarding homosexuality and the rights of women (Razak, 2008). These arguments appear to be resonating in Canadian public opinion. More than two thirds of Canadians perceive an "irreconcilable" conflict between Islamic and 
Western societies (Leger Marketing Research, 2011), and, in the World Values Survey, nearly 12 percent of Canadians, and nearly one in four Quebecers, did not want Muslims as neighbors (European Values Study Group and World Values Survey Association, 2010). Indeed, less than half of all Canadians hold a positive perception of Muslims (Jedwab, 2011). In this respect, the Canadian public opinion environment resembles those in many European countries, including the Netherlands (Mepschen, Duyvendak and Tonkens, 2010: 965).

This paper examines the level and drivers of Canadian Muslims' opinions about the legal recognition of same-sex relationships. The recognition of same-sex marriage by the Parliament of Canada in 2005 is among the signature liberal achievements in Canadian politics in the past half-Century. This achievement did not happen all of a sudden. It was the culmination of a decades-long pattern of political activism and social movement politics, as well a series of legal, political and public opinion shifts regarding gays and lesbians. In the 1982 World Values Survey, a majority of Canadians, 51 percent, expressed the view that homosexuality was "never justifiable;" that figure fell to 37 percent in 1990, 26 percent in 2000, and 20 percent in 2006. Nowadays, a majority of Canadians (61\%) support same-sex marriage, and an overwhelming majority $(85 \%)$ support at least some form of legal recognition for same-sex couples (Ipsos, 2011). Nonetheless, the recognition of same-sex marriage rights was staunchly opposed by the leaders of major religious groups in Canada-including Catholic, Muslim, Jewish and other leaders-and this opposition remains a legitimate conservative position in Canadian political discourse. In this respect, opinions about same-sex relationships are a high bar to use in assessing the extent to which people's opinions are "compatible" with a liberal cultural environment.

Drawing an analytical boundary around the category "Muslim" risks privileging from the outset explanations that draw attention to the lone characteristic that all Muslims, by definition, share in common: Islam. As a group, however, Muslims are distinctive from other Canadians, and indeed from other immigrants and religious groups, in more than simply their religious convictions. There are different "proportionalities" of people with certain characteristics inside of the category "Muslim" than there are outside of this category. The core finding of this paper is that the treatment of Muslims as a monolithic social group masks variations within the Muslim community in terms of characteristics that are associated in systematic ways, for Muslims and non-Muslims alike, with public opinion about liberal political issues, and, in particular, with opinions about same-sex marriage. 
The remainder of the paper is divided into four sections. The next section examines the characteristics and opinions of Canada's Muslim community. This analysis suggests that Muslim-Canadians do indeed stand out as a group for their negative opinions about same-sex relationships, but that the explanation for this distinctiveness is unclear. The third section proposes and tests two plausible explanations for the distinctiveness of Muslims, and summarizes data that allow for tests of these hypotheses. The "religiosity hypothesis" attributes conservatism among Muslims to Islam, whereas the "foreign socialization hypothesis" suggests that many Muslims bring with them the conservatism of the countries from which they emigrated. These hypotheses are not mutually exclusive, but they do generate different implications. The fourth section tests these implications systematically. This part of the analysis draws on a large web-based public opinion survey of Canadian voters. Section five, the conclusion, discusses the implications of the results for the framing of the debate surrounding Muslim immigration. The core findings are, first, that it is religiosity in general, and not Islam in particular, that generates opposition to same same-sex marriage; and second, that a Canadian socialization, and not simply secularization, undoes these opinions. There appears to be nothing about a commitment to Islam in particular that generates or preserves, more than other religions, opposition to same-sex relationships.

\section{Profile of Canadian Muslims}

The overwhelming majority of Muslim-Canadians are foreign-born. The top left-hand panel in Figure 1 highlights the relative proportions of major religious groups that were born in Canada and abroad (Statistics Canada, 2001). The remainder of the panels summarize, for the immigrants within each religious group, their distributions in terms of their region of birth and length of residence in the country. Canadian Muslims are overwhelmingly recent immigrants. At the time of the Census, 72 percent of Muslims were foreign-born, compared to just over 18 percent of the Canadian population as a whole. Two-thirds of Muslim immigrants had arrived to Canada within 10 years of the census, and more than 40 percent had arrived within five years. The comparable figures for immigrants as a whole were 34 and 18 percent, respectively. Canadian Muslims also tend to immigrate from specific regions of the world. Fully 9o percent of Muslim immigrants to Canada arrive from the Middle East (35\%), South Asia (27\%), and Africa $(25 \%)$, and just six percent arrive from Europe and East Asia. By contrast, 
fewer than one in six non-Muslim immigrants arrive from Africa, the Middle East, and South Asia, and the majority of immigrants to Canada are from European (40\%) and Eastern Asian (13\%) countries. Muslims therefore differ from most other religious groups in that they are overwhelmingly immigrants, and they differ from most other immigrant groups in that they are overwhelmingly recent immigrants and from South Asia, the Middle East and Africa.
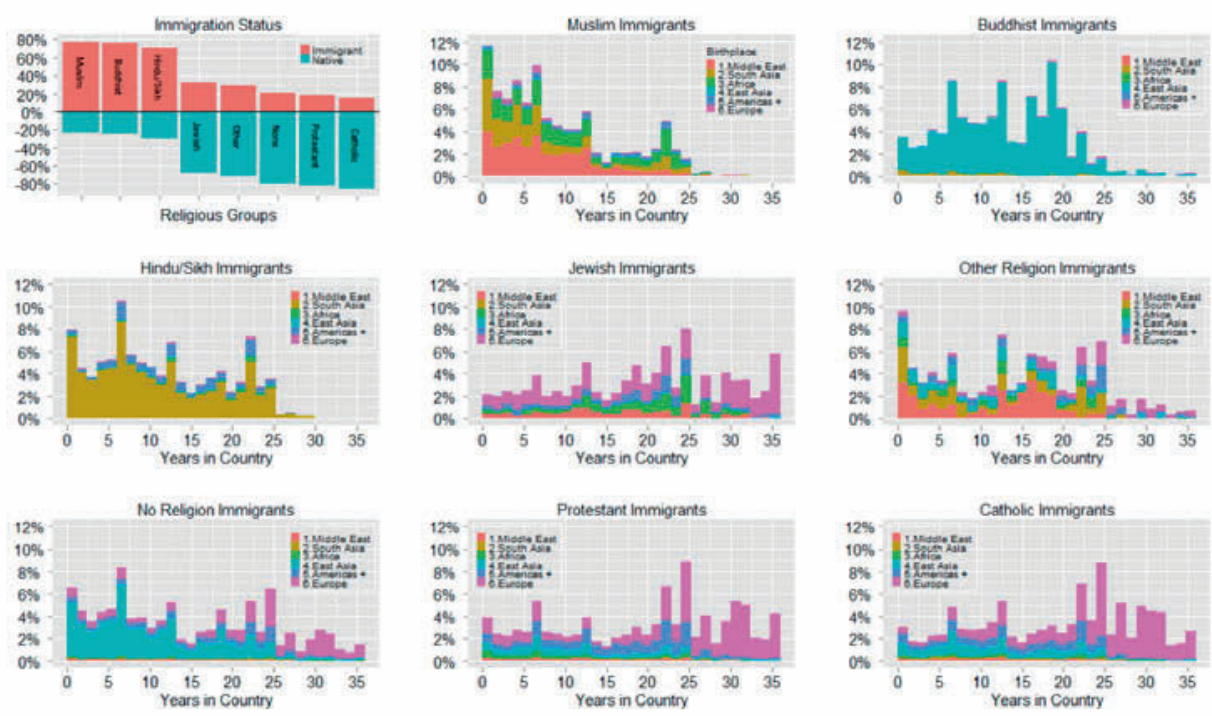

Figure 1 Immigration Status of Major Religious Groups in Canada

Source: Statistics Canada, 2001 Census of Canada.

Figure 2 summarizes in a broad cross-national perspective public opinion about homosexuality. The y-axis corresponds to the national average of respondent positions in the two most recent waves of the World Values Survey (1999-2006) on a question which asks them to situate their views about homosexuality from a low of 1 ("is never justifiable") to a high of 10 ("is always justifiable"). The x-axis summarizes the country's score on the UN Human Development Index (United Nations Human Development Programme, 2011). The colors and shape of the points correspond to different regions of the world, and the size of the points reflects the size of the Muslim population in each country. The LOESS smoother summarizes the relationship between level of HDI and public opinion about homosexuality. 


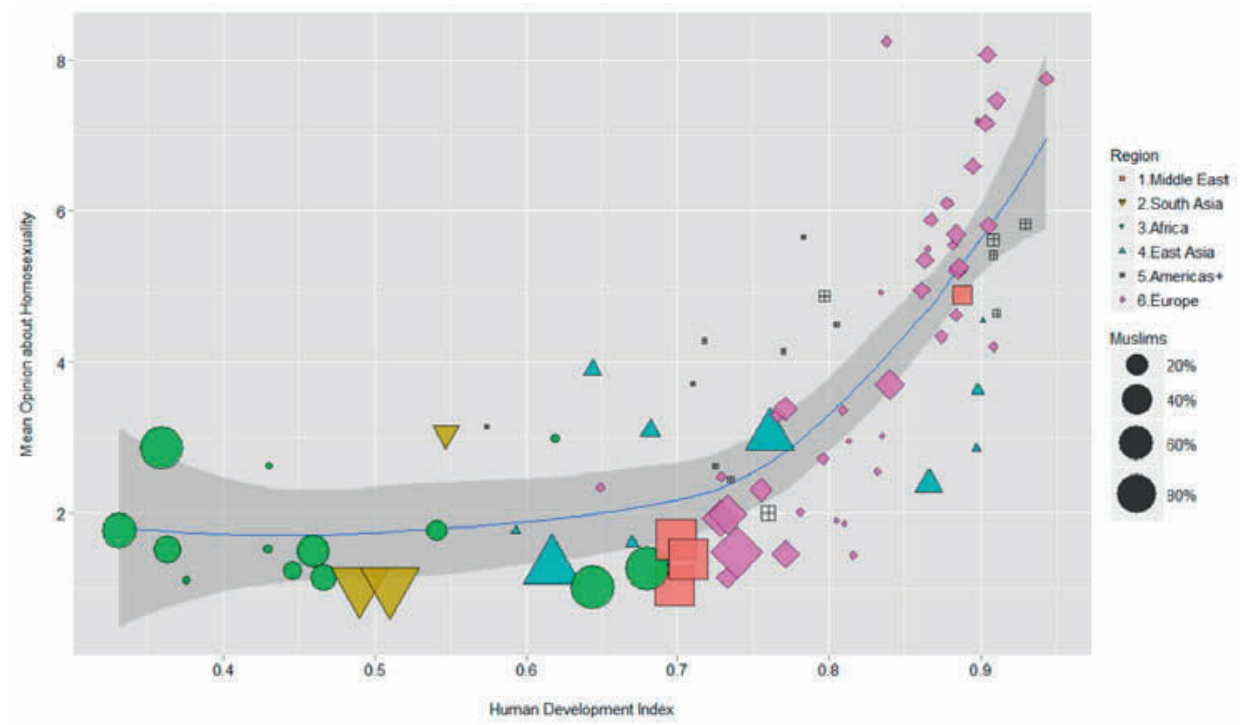

Figure 2 Public Opinion about Homosexuality in Comparative Perspective

Sources: World Values Survey, 1996-20o6; Human Development Index, 2011; Pew Research Center, 2010.

Two findings emerge from Figure 2. First, as Inglehart and Norris (2003) find, public opinion in Muslim majority countries is invariably negative toward homosexuality. The larger points are clustered toward the low end of the y-axis. Fully 99 percent of Jordanians and Bangladeshis responded that homosexuality was "never" justifiable, as did 96 percent of Pakistanis, 93 percent of Algerians, 91 percent of Indonesians, 88 percent of Iranians, and 79 percent of Turks. The comparable figures among non-Muslim countries are not in the general vicinity of these levels. Indeed, using the percentage of a country's Muslim population to predict public hostility toward homosexuality accounts for about a fifth of the variation of the points in the figure.

Yet, second, opinions about homosexuality are powerfully related to a country's score on the UNDP's Human Development Index. Certainly, this basic finding is consistent with existing accounts of value change in postindustrial societies (Inglehart, 1997). But it also raises questions about the extent to which the prevalence of Islam rather than level of socioeconomic development accounts for the distinctiveness of Muslim countries. Indeed, opinion in Muslim majority countries is hardly more hostile toward homosexuality than is opinion in other countries at comparable levels of $\mathrm{HDI}$, or in the same regions of the world. Public opinion in African countries, for example, is unanimously negative about homosexuality, regardless of 
the proportion of the Muslims in the country. 96 percent of Zimbabweans and 90 percent of Ugandans-both countries with small Muslim populations-indicated that homosexuality was never justifiable. From this vantage point, notice that the position of Muslim majority countries in Figure 2 is not much lower-and is in some cases higher-than the line which depicts the relationship between HDI and opposition to homosexuality. Taking into account the level and non-linear effect of HDI reduces by two-thirds the magnitude of the relationship between the proportion of Muslims in a country and the country's average level of opposition to homosexuality. This relation-ship is only barely significant statistically $(\mathrm{t}=\mathbf{- 2 . 2})$. In short, Muslim countries do not appear to stand out, or at least not by much, from other countries at similar levels of socioeconomic development.

Taken together, there are strong reasons for supposing that Muslim-Canadians will tend to express a negative opinion toward same-sex marriage. Most Muslim-Canadians are recent immigrants from areas of the world where there is virtually unanimous opposition to homosexuality. Indeed, the prevalence of liberal attitudes toward homosexuality is a rather recent phenomenon in Canada, and if not for drastic changes in Canadian public opinion during the 1980 s-which very few Muslims were in the country to experience-the level of support for gay rights in Canada would resemble nothing like it does today.

\section{Public Opinion about Same-Sex Marriage}

This part of the analysis draws on two large public opinion polls of the Canadian electorate taken immediately after the 2006 and 2011 federal elections (Ipsos, 2006, 2011). These surveys are, for present purposes, two "opt-ins" away from randomization. Respondents opt-in first, in effect, to the election, and they opt in second to the survey. Relative to their shares of the Canadian population, men and immigrants are under-represented in these surveys. Men comprise 38 percent of the sample and 49 percent of the Canadian population. Immigrants make up 21 percent of the population, but just 11 percent of the sample. Older people are overrepresented. The mean age of survey respondents is 53 , compared to a mean age of 37 in the Canadian population as a whole, and 46 among the voting-age population. These differences are due in part to the facts that these are surveys of the electorate and because they are opt-in web surveys (Chang and Krosnick, 2009). 
An important advantage of these data, however, is that the sample sizes are very large. The 2006 survey has 36003 respondents, including 160 Muslims. The 2011 survey has 39261 respondents, including 250 Muslims. Surveys of this size permit reliable statistical analyses of minority subgroups, such as Muslims, that are statistically invisible in other surveys. Moreover, both surveys ask respondents for their opinions about same-sex marriage. These question wordings, outlined in Table 1, are not identical, but they are sufficiently similar to permit a pooling of the data on these questions, and thus a further increase of the sample size of minority sub-populations. Indeed, the answers of respondents to these questions are very similar at both time-points. In 2006, 53 percent of respondents supported same-sex marriage, compared to 35 percent that supported civil unions, and a further 13 percent that supported neither of these. In 2011, 61 percent supported same-sex marriage, 25 percent civil unions, and 14 percent were opposed to any form of recognition.

\section{Table 1 Survey Items on Same-Sex Marriage}

\begin{tabular}{lll}
\hline Year & Question Wording & Options \\
\hline 2006 & Which comes closes to your views about & 1. They should be allowed to legally marry; \\
& gay and lesbian couples, do you think: & $\begin{array}{l}\text { 2. They should be allowed to legally form civil unions, } \\
\text { but not marry; }\end{array}$ \\
& $\begin{array}{l}\text { 3. There should be no legal recognition of their } \\
\text { relationships }\end{array}$ \\
2011 & $\begin{array}{l}\text { 1. Favour same-sex marriage; } \\
\text { What is your view on same-sex } \\
\text { marriage? }\end{array}$ & $\begin{array}{l}\text { 2. Oppose same-sex marriage, but would accept } \\
\text { same-sex civil unions; }\end{array}$ \\
& 3. Oppose entirely same-sex marriage
\end{tabular}

Source: Ipsos, Election Exit Poll, 2006/2011.

Figure 3 outlines how respondents from different religious groups answered these questions about same-sex marriage. The lighter bars on the left side of the figure correspond to the proportion of each group that supports full-fledged marriage rights for gays and lesbians, and the darker bars on the right correspond to the proportion that opposes to all forms of recognition. The middle bars represent the proportions favoring civil unions. 


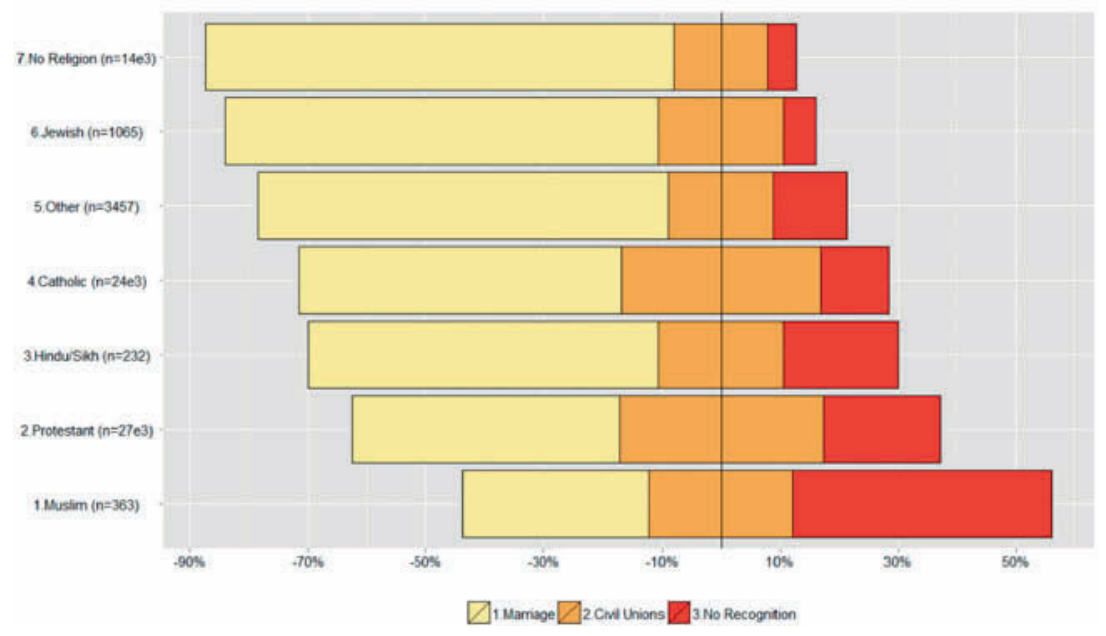

Figure 3 Opposition and support for Same-Sex Relationships

Source: Ipsos, Election Exit Poll, 2006/2011.

Respondents with no religion expressed the highest levels of support for same-sex marriage. Less than five percent of those with no religion opposed any form of recognition of same-sex relationships, and 78 percent supported same-sex marriage. The comparable figures for the next closest group, Jewish respondents, were 13 and 70 percent, respectively. The results are altogether different, however, among Muslim respondents. Muslims stand out from other religious groups in Canada for their level of opposition to same-sex marriage. Indeed, Muslims are the only group for whom the proportion opposing any form of recognition for same-sex couples, 44 percent, is larger than the proportion, 32 percent, that supports same-sex marriage. Protestants are the next closest group in terms of opposition to gay marriage. Even then, however, there are more than two Protestants that support same-sex marriage for every one Protestant that opposes all forms of recognition (45\% vs. $20 \%$ ). Muslims, in short, are the only one of these religious groups wherein there is a very substantial level of opposition to any form of recognition of same-sex relationships.

\section{Data and Hypotheses}

Both surveys include measures for immigration status, frequency of religious observance, and level of formal education. The 2011 survey includes additional questions about length of residence in the country, region of 
origin, and a battery of questions about religiosity. The variables and question wordings are summarized in Table 2.

Table 2 Variables and Question Wording

\begin{tabular}{|c|c|c|c|}
\hline Year & Name & Question Wording & Categories \\
\hline \multirow[t]{3}{*}{2006} & IMMIGRANT & Were you born in Canada? & $\begin{array}{l}\text { 1. Immigrant } \\
0 . \text { Native }\end{array}$ \\
\hline & CHURCHATT & $\begin{array}{l}\text { 0ther than on special occasions...how often } \\
\text { did you attend religious services or meetings } \\
\text { in the last } 12 \text { months? }\end{array}$ & $\begin{array}{l}\text { 3. + Once a week } \\
\text { 2. Once a week } \\
\text { 1. Once a month+ } \\
\text { 0. Less often }\end{array}$ \\
\hline & EDUCATION & Education Level & $\begin{array}{l}\text { 6. Graduate degree } \\
\text { 5. University degree } \\
\text { 4. Some university } \\
\text { 3. College diploma } \\
\text { 2. Some college } \\
\text { 1. High School } \\
\text { 0. No High School }\end{array}$ \\
\hline \multirow[t]{8}{*}{2011} & IMMIGRANT & Were you born in Canada? & $\begin{array}{l}\text { 1. Immigrant } \\
0 . \text { Native }\end{array}$ \\
\hline & YEARSCDA & In what year did you come to Canada? & $\begin{array}{l}\text { 5. Before } 1959 \\
\text { 4. } 1960-9 \\
\text { 3. } 1970-9 \\
\text { 2. } 1980-9 \\
\text { 1. } 1990-9 \\
0.2000-11\end{array}$ \\
\hline & BIRTHPLACE & Where specically did you move from? & $\begin{array}{l}\text { 1. Middle East } \\
\text { 2. South Asia } \\
\text { 3. Africa } \\
\text { 4. East Asia } \\
\text { 5. Americas+ } \\
\text { 6. Europe }\end{array}$ \\
\hline & CHURCHATT & $\begin{array}{l}\text { How often do you attend church, temple, } \\
\text { mosque services at your place of worship? }\end{array}$ & Same as 2006 \\
\hline & RELIGIMP & $\begin{array}{l}\text { In your life, would you say religion is very } \\
\text { important, somewhat important, not very } \\
\text { important, or not important at all? }\end{array}$ & $\begin{array}{l}\text { 3. Very } \\
\text { 2. Somewhat } \\
\text { 1. Not very } \\
0 . \text { Not at all }\end{array}$ \\
\hline & PRAYERS & Do you believe in a God that answers prayers? & $\begin{array}{l}\text { 1. Yes } \\
0 . \text { No }\end{array}$ \\
\hline & HOLYBOOK & $\begin{array}{l}\text { Do you believe that the holy book of your } \\
\text { religion...is the revealed word of God? }\end{array}$ & $\begin{array}{l}\text { 1. Yes } \\
0 . \text { No }\end{array}$ \\
\hline & EDUCATION & Education Level Same as 2006 & \\
\hline
\end{tabular}


The religiosity hypothesis generates two expectations. On the one hand, the distinctiveness of Muslims may be attributable to their higher level of religiosity (Adamczyk and Pitt, 2009; Boswell, 1980; Rimmerman, Wald and Wilcox, 2000). In this case, Muslims are not distinctive because of Islam per se, but because religiosity is associated with heightened opposition to same-sex marriage, and Muslims are more religious than other Canadians. Controlling for level of religiosity should therefore reduce the magnitude of the difference between Muslims and non-Muslims. On the other hand, however, the distinctiveness of Muslims may be attributable to the effects of Islam in particular (Hekma, 2002). In this scenario, religious Muslims stand out from other religious Canadians because a commitment to Islam is associated with more negative opinions about same-sex marriage than is a commitment to other religions, such as Catholicism and Protestantism.

If the foreign socialization hypothesis is correct, then the gap between Muslims and non-Muslims is attributable primarily to the distinctive opinions of Muslims socialized in foreign countries. Formal education may also play a role. The cause of the empirical relationship between formal education and liberal values is a matter of some debate (Abramson and Inglehart, 1994; Dutch and Taylor, 1993; Jennings and Niemi, 1981; Warwick, 1998). Nevertheless, Weil (1985) finds that this relationship is conditional on the prevalence of liberal democracy in a country. Thus, the effects of education may differ for people that receive their education in Canada than for people that receive their education in non-liberal countries. If this is correct, then a high level of formal education may decrease opposition to same-sex marriage among Canadian-born Muslims-who would have received their education in Canada-but not among foreign-born Muslims-who would have received most, if not all, of their formal education in Africa, the Middle East, or South Asia. The muted effects of formal education on the opinions of foreign-born Muslims, moreover, could contribute to the distinctiveness of Muslims as a group in their opinions about same-sex marriage.

The place to begin is with the data. Figure 4 summarizes for each religious group the basic bivariate relationship between level of religious attendance, on the x-axis, and opposition to all forms of legal recognition of same-sex relationships, on the y-axis. The size of the points reflects the proportion of each religious group at each level of religious attendance. 


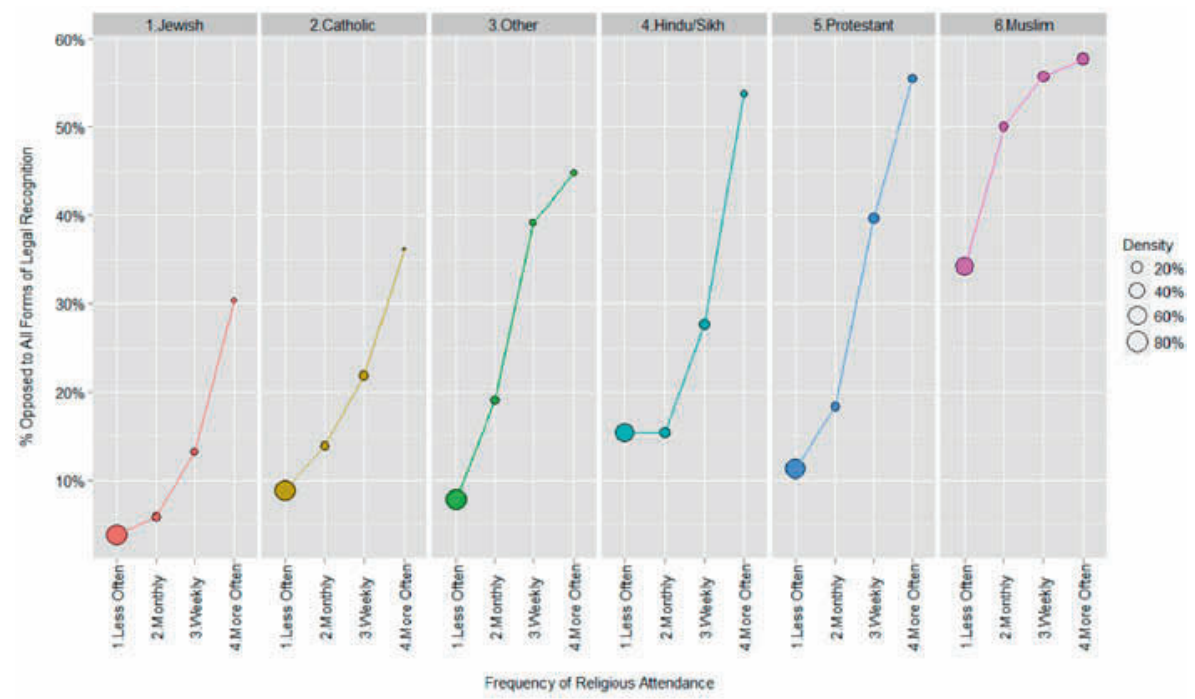

Figure 4 Opposition to Legal Recognition of Same-Sex Relationships, by Religious Attendance

Sources: Ipsos, 2006 and 2011.

A few findings emerge in Figure 4. First, notice the size of the data points at different levels of church attendance. The vast majority of Jews $(80 \%)$ Catholics (76\%), Protestants (66\%), and Other Religions (81\%) attend religious ceremonies only infrequently - less than once a month. Only 10 percent of Jews and 15 percent of Catholics attend religious ceremonies on a weekly basis, and less than 3 percent attend religious ceremonies more than once a week. The comparable figures are somewhat higher, but nonetheless quite low, for Protestants $(24 \%, 8 \%)$ and Hindu/Sikhs $(19 \%$, $5 \%)$. For Muslims, however, nearly half (45\%) attend a religious ceremony at least once a month, and fully one in five attend more than once a week. In this respect, Muslims are disproportionately represented among the higher levels of religious attendance where opposition to same-sex relationships is especially pronounced.

Notice, however, that the gap between people who rarely and regularly attend religious ceremonies is less pronounced among Muslims than among the members of any other religious group. Indeed, the 24 percentage point difference between Muslims who attend religious ceremonies more than once a week, and the Muslims who attend less than once a month, is dwarfed by the 45 point spread between Protestants in these categories, and the 39 and 37 point spreads among Hindu/Sikhs and Other Religions, respectively. 
Notably, the Muslim respondents that stand out the most from the other religious groups are not the Muslim respondents that attend religious ceremonies on a regular basis. With the exception of Catholics and Jews, people who frequently attend religious ceremonies are generally quite negative, at least compared to other Canadians, in their opinions about the legal recognition of same-sex relationships. In this regard, Muslims are not much different. Rather, where Muslims are different is in the level of opposition to same-sex relationships that exists among Muslims who attend religious ceremonies only rarely, if at all. These Muslims oppose at more than three times the rate of the infrequent attenders among other religions the legal recognition of same-sex relationships. There are a few potential explanations for this finding, not least of which is that religious attendance may be a less effective indicator of religious commitment among Muslims than among non-Muslims. Section Four examines this possibility in greater detail.

Figure 5 summarizes for native-born and foreign-born respondents within each religious group the relationship between level of education and opposition to the legal recognition same-sex relationships. The horizontal lines on each panel represent the averages for each sub-group.

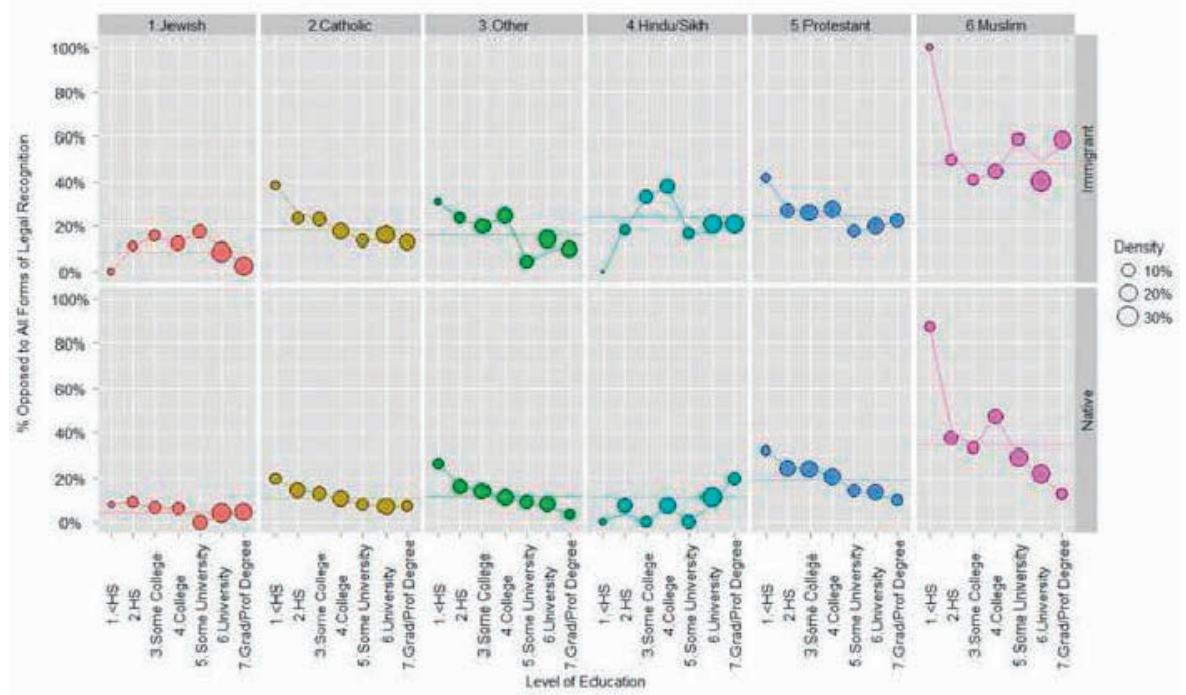

Figure 5 Opposition to Legal Recognition of Same-Sex Relationships, by Level of Education

Sources: Ipsos, 2006 and 2011. 
On the whole, 19 percent of foreign-born Canadians oppose any form of recognition of same-sex relationships, compared to 13 percent of native-born Canadians. This basic relationship persists among all religious groups, but it is especially pronounced among Muslims. Nearly half of all foreign-born Muslims, 49 percent, oppose any recognition of same-sex relationships, compared to 34 percent among native-born Muslims.

Level of education is consistently and inversely associated with opposition to same-sex relationships. More highly educated respondents express higher levels of support for same-sex relationships than do their counterparts with lower levels of formal education. Notice in particular the trends among Muslims. Interestingly, the magnitude of the effect of formal education on opinions about same-sex marriage is by a considerable extent largest among native-born Muslims (Coef $=-.366$, se $=.119)$; yet, the effect is altogether non-existent among foreign born Muslims (Coef $=-.023, \mathrm{se}=.08)$. Foreign-born Muslims are just as likely to oppose same-sex relationships, regardless of their level of education. And while native-born Muslims with a university degree harbor opinions that are virtually indistinguishable from the opinions of all other Canadians with a university degree, the opinions of native-born Muslims with less than postsecondary education are indistinguishable from the opinions of foreign-born Muslims.

\section{Multivariate Analysis}

This stage of the analysis is confined to the 39261 respondents in the 2011 survey, which contains more precise measures of religiosity, country of birth, and length of exposure to the country. The indicators of religiosity, summarized in Table 2, are church attendance, importance of religion, whether the Holy Book is the revealed word of God, and whether God answers prayers. Interestingly, church attendance is the weakest loading variable on this factor for all religions; it is especially weak among Muslims, and doubly weak among Muslim women. This suggests that religious attendance is a less effective indicator of underlying religiosity among Muslims than among other religious groups, and it may explain the findings, uncovered above, that Muslims stand out in their opinions among gay marriage more strongly among non-Mosque-attenders than among regular Mosque-attenders. Even so, the remaining three items-HOLYBOOK, GODPRAYERS, and RELIGIMP-constitute a highly reliable and single dimensional measure of religiosity that applies equally to all of the religious groups. After standardizing these variables with a mean of $o$ and standard 
deviation of 1 , they haven been weighted by their factor loadings and added together to form a three item index of religiosity $(\alpha=.84)$, which has itself been standardized, for ease of interpretation, with a standard deviation of 1 and a minimum value of 0 .

\subsection{Drivers of Opinions about Same-Sex Marriage}

The dependent variable is comprised of three categories. Support for same-sex marriage is the first category (1), support for civil unions is the second category (2), and opposition to all forms of recognition is the third category (3).These categories are not perfectly ordinal. The parallel regression assumption is violated. Even so, closer analysis indicates that these differences are questions of magnitude rather than of direction. Some variables do somewhat more heavy lifting in predicting the distinction between the first and second categories than between the second and third, and some variables do more between the second and third than between the first and the second. The variables that predict opinions between the first and the second categories, however, also predict, in the same direction and to approximately the same extent, opinions between the second to the third. The violation of the parallel regression assumption is therefore not so severe to warrant transforming the dependent variable into two categories, or of employing less parsimonious regression models suited to nominal dependent variables. Missing data are not a problem for this stage of the analysis. The survey required respondents to provide answers about most sociodemographic information-including gender, education, immigration status, and country of birth. Even so, the survey did provide opportunities for respondents to not answer some questions. Only 507 observations, however, or one percent of the sample, are missing on religion, and fewer still, 233, are missing on religiosity. In effect, the covariates in the model are complete. Where there is missing data is on the question of same-sex marriage, where 2773 observations, or seven percent of the sample, are missing. Given that the covariates are complete, however, using these variables to impute values of the dependent variable can add no additional information, at least to the extent that the pattern of missing values on the dependent variable is random (Little, 1992). To the extent that these patterns are not random, moreover, multiple imputation does not solve the problem. Further analysis indicates that the patterns of missing data on same-sex marriage are largely random. Using the full battery of independent variables to predict missing observations on the question of same-sex marriage adds just a tenth of a percentage point to predictive accuracy of the naive prediction that no cases are missing. 


\subsection{Religiosity Hypothesis}

Table 3 outlines in three stages the results of an Ordinal Logistic Regression model that uses religion and religiosity to predict respondent positions on same-sex marriage. The first bloc of the model assesses the impact of respondent religion, controlling for age and gender. The second bloc controls for level of religiosity, and the third bloc, an interaction model, controls for possible differences in the effect of religiosity across religious groups. All of the models include age and gender because these variables are related simultaneously with level of religiosity and with opinions about same-sex marriage. In all of the models, the largest religious group, Catholic, is the reference category. Thus, the coefficients for the different religious groups reflect a comparison to Catholics. Moreover, the use of interaction terms in the third model means that it is not possible to compare directly in this model the direct effects of religion and religiosity, given that their values are conditional in the interaction model on the values of the other variables with which they interact.

Table 3 Religion, Religiosity and Opinions about Same-Sex Marriage

\begin{tabular}{lccc}
\hline & Bloc 1 & Bloc 2 & Bloc 3 \\
\hline Age & $0.023^{*}$ & $0.020^{*}$ & $0.021^{*}$ \\
Male & $(0.001)$ & $(0.001)$ & $(0.001)$ \\
& $0.582^{*}$ & $0.796^{*}$ & $0.796^{*}$ \\
Protestant & $(0.022)$ & $(0.023)$ & $(0.023)$ \\
& $0.353^{*}$ & $0.282^{*}$ & $-0.388^{*}$ \\
Muslim & $(0.025)$ & $(0.025)$ & $(0.063)$ \\
& $1.753^{*}$ & $1.367^{*}$ & 0.188 \\
Jewish & $(0.140)$ & $(0.142)$ & $(0.503)$ \\
& $-0.902^{*}$ & $-0.666^{*}$ & $-0.724^{*}$ \\
Hindu/Sikh & $(0.101)$ & $(0.105)$ & $(0.200)$ \\
& 0.135 & 0.092 & $-1.217^{*}$ \\
Other & $(0.181)$ & $(0.187)$ & $(0.576)$ \\
& $-0.358^{*}$ & $-0.129^{*}$ & $-1.259^{*}$ \\
None & $(0.061)$ & $(0.063)$ & $(0.156)$ \\
& $-1.046^{*}$ & -0.006 & $-0.265^{*}$ \\
Religiosity & $(0.035)$ & $(0.040)$ & $(0.056)$ \\
& & $0.832^{*}$ & $0.639^{*}$ \\
Protestant.Religiosity & & $(0.015)$ & $(0.023)$ \\
& & & $0.366^{*}$ \\
Muslim.Religiosity & & $0.032)$ \\
& & & $0.587^{*}$ \\
& & & $(0.221)$
\end{tabular}




\begin{tabular}{lccc}
\hline & Bloc 1 & Bloc 2 & Bloc 3 \\
\hline Jewish.Religiosity & & & 0.003 \\
& & $0.116)$ \\
Hindu/Sikh.Religiosity & & $0.728^{*}$ \\
& & & $(0.287)$ \\
Other.Religiosity & & $0.684^{*}$ \\
& & & $(0.083)$ \\
None.Religiosity & & 0.014 \\
& & & $0.050)$ \\
cut1 & $1.884^{*}$ & & \\
cons & $(0.049)$ & $3.186^{*}$ & $2.888^{*}$ \\
& & $(0.057)$ & $(0.063)$ \\
cut2 & & \\
cons & $3.351^{*}$ & $4.778^{*}$ & $4.490^{*}$ \\
& $(0.052)$ & $(0.061)$ & $(0.065)$ \\
N & & & 35948 \\
pseudo $R^{2}$ & 35948 & 0.121
\end{tabular}

Standard errors in parentheses. ${ }^{*} p<0.05$

Source:Ipsos 2011.

Given the results of the earlier analysis, it is not surprising that Muslims stand out in the first bloc of the model. Compared to the sample as a whole, and holding gender and age constant at their mean level, the predicted probabilities indicate that Muslims are three times less likely to support same-sex marriage ( $21 \%$ vs. $63 \%$ ) and nearly four times more likely to oppose all forms of recognition for same-sex relationships ( $47 \%$ vs. $12 \%)$. The 95 percent confidence intervals are in the vicinity of plus or minus five percentage for Muslims and plus or minus a half a percentage point for the sample as a whole. For the next most conservative group, Protestants, $5^{2}$ percent support same-sex marriage, and only 18 percent oppose all forms of recognition. Protestants are significantly less conservative than Muslims, but significantly more conservative than Jews, for example. Fully 79 percent of Jews support same-sex marriage rights, and just five percent oppose all forms of recognition.

Introducing level of religiosity, in Bloc 2, substantially improves the fit of the model. Muslim Canadians are more religious than non-Muslims. On the religiosity scale, which ranges from a low of o to a high of 2.6, the mean score for Muslims is $2.1(\mathrm{sd}=0.7)$, which is more than a third of a standard deviation higher than the next closest group, Protestants (1.8, $s d=.9$ ), and more than two thirds of standard deviation higher than the 
national average $(1.4, \mathrm{sd}=1)$. This contributes to the distinctive opinions of Muslims. According to these estimates, if Muslims were no more religious than other Canadians, then 33 rather than 21 percent of Muslims would support same-sex marriage, and only 29 rather than 47 percent would oppose all forms of recognition. On its own, religiosity accounts for about $3^{6}$ percent of the opinion gap between Muslims and non-Muslims in Canada.

This evidence supports one part of the religiosity hypothesis. It turns out that the higher level of religiosity among Muslims accounts for a sizeable portion of their distinctive positions about same-sex marriage. What is not clear, however, is whether Islamic religiosity generates to a greater extent than other kinds of religiosity opposition to same-sex marriage. This is the key assumption underlying arguments that single out Islam as a set of religious beliefs that generates illiberal opinions about gay rights.

The evidence in Bloc 3 provides limited support for this line of argument. This bloc of the model includes interaction terms for religiosity by religion. Bloc 3 improves the fit of the model, even taking account of the additional number of variables, but only marginally $\left(\operatorname{LR} \chi^{2}=200\right)$. Nonetheless, a number of relevant findings emerge from this bloc of the model. The baseline category is Catholics. Given that these are interaction terms, the religiosity variable now represents the effect of religiosity for Catholics; the Religion variables now represent the direction and magnitude of the difference between each religious group and Catholics when the level of religiosity is at its lowest possible value; and in order to calculate the total effect of religiosity for each religious group, one must add the coefficient for Religiosity to the coefficient of the interaction term for that particular group.

Notice that Muslims continue to stand out from the other groups-though not so much from Catholics-even when the level of religiosity is at its lowest possible value. Protestants, Jews, Hindus and Sikhs, members of other religions and members of no religion are all more liberal than Catholics when level of religiosity is at its lowest possible value. Muslims, however, are not more liberal. Even so, notice as well that although the effect of religiosity is larger among Muslims than among Catholics, it is not larger among Muslims than it is among Hindus/Sikhs and members of Other Religions; indeed, the effect is not larger at statistically significant levels among Muslims than among Protestants.

Figure 6 summarizes the key results of the regression model. The horizontal lines in Figure 6 correspond to the the average levels of support and opposition to same-sex marriage in the entire sample. The bars in the Figure represent the predicted levels of support and opposition to same-sex marriage among Muslims, but under different scenarios about the level and 
impact of Islamic religiosity. These scenarios are summarized along the $\mathrm{x}$-axis. The leftmost scenario is the predicted level of support and opposition to same-sex marriage among Muslims under the assumption that both the level and effect of religiosity among Muslims are constant at their observed levels among Muslims, controlling for age and gender. The second scenario reflects the same prediction, and also holds the level of religiosity constant at its observed level among Muslims, but in this case it adjusts the effect of religiosity to its average level among all Canadians, rather than to its observed level among Muslims. And finally, the third scenario holds the effect of religiosity constant at its observed level among Muslims, but adjusts the level of religiosity to its average level in the sample as a whole. Figure 6 therefore makes it possible to compare the distinctive contributions of both the level and effect of Islamic religiosity on the size of the opinion gap between Muslim and non-Muslim Canadians.

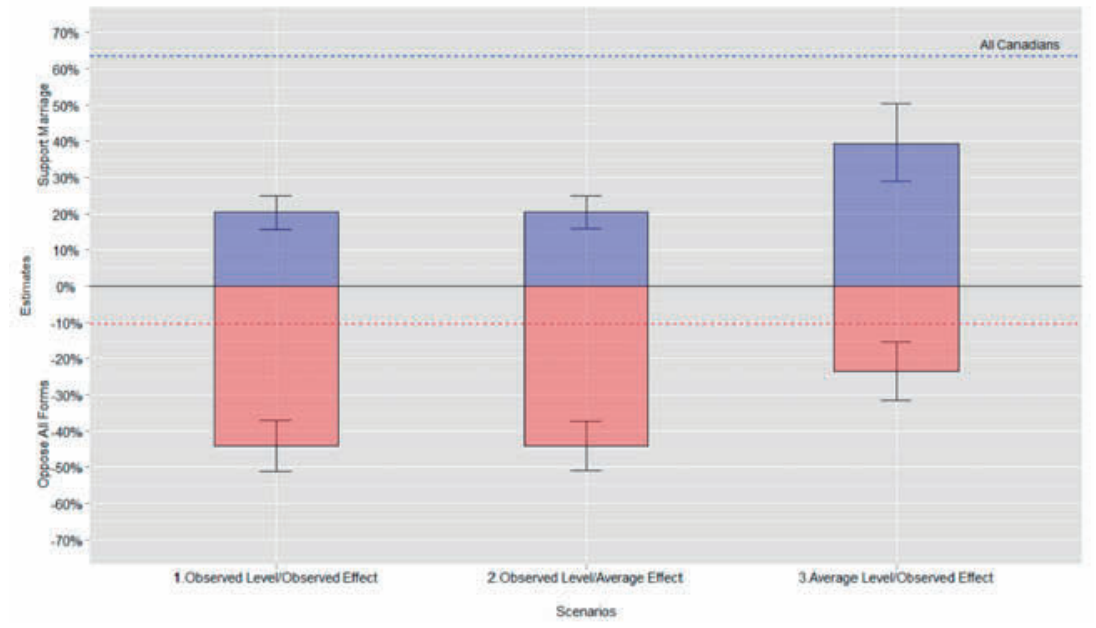

Figure 6 Muslim Opinions about Same-Sex Relationships, by Level and Effect of Religiosity

Sources: Ipsos , 2006 and 2011.

The main finding is that it is in large part the higher level of religiosity among Muslims, and not at all the effect of Islamic religiosity in particular, that explains the opinion gap on same sex marriage between Muslims and non-Muslims in Canada. Notably, controlling for the effect of Islamic religiosity does not reduce the size of the opinion gap between Muslims and non-Muslims. Muslims are just as different from the national averages in the second scenario, when the effect of Islamic religiosity is assumed to 
be identical to the effect of religiosity among all Canadians, as in the first scenario, when the effect of religiosity is set to the value observed among Muslims. The size of the opinion gap decreases substantially, however, when the greater level of religiosity among Muslims is taken into account.

\subsection{Foreign Socialization Hypothesis}

There are a few ways in which foreign socialization may influence opinions about same-sex marriage. First, it may influence these opinions directly. Recent immigrants to Canada who were born and socialized in regions of the world where there is widespread opposition to homosexuality may harbor negative opinions about same-sex marriage by virtue of their high levels of exposure to the opinion environments in their countries of origin, and their low levels of exposure to the opinion environment in Canada. Second, however, foreign socialization may also affect opinions indirectly, through religiosity. If immigrants happen to be more religious than nativeborn Canadians, then they may stand out for their opinions about gay marriage in part by virtue of their higher levels of religiosity. This would be an indirect effect of foreign socialization, and it suggests that controlling for religiosity would mitigate to some extent the effect of foreign birth and socialization on public opinion about gay marriage.

Closer analysis, however, rules out this second possibility. Immigrants are indeed more likely than native-born Canadians to attend religious services, but, intriguingly, they do not score higher than native-born Canadians on the three-item measure of religiosity (1.4 for native born vs. 1.4 for immigrants). This non-finding applies equally to Muslims (2.1 for native born vs. 2.2 for foreign born). Moreover, the effect of religiosity on opinions about same-sex marriage is equally as strong for native-born as it is for immigrant-Canadians-indeed, if anything, the effects of religiosity are slightly stronger among the native-born than among immigrants. The pattern also applies for Muslims. In short, whatever impact foreign socialization has on opinions about same-sex marriage, these effects operate independently of the level and effects of religiosity.

Table 4 replicates the analysis from Table 3 , except in this case the variables in the third bloc of the regression model in Table 3 -which examined differences in the effects of religiosity across religious groups, and found that these differences had no impact on the distinctiveness of Muslims-are replaced by a different set of variables which measure the region of the world from which the respondents emigrated. The six regional categories are Middle East, South Asia, Africa, East Asia, Americas+, and Europe. Native-born respondents are the reference category. 
Table 4 Religion and Region of Origin as Predictors of Opinions about Same-Sex Marriage

\begin{tabular}{|c|c|c|c|}
\hline & Bloc 1 & Bloc 2 & Bloc 3 \\
\hline Age & $\begin{array}{c}0.023^{*} \\
(0.001)\end{array}$ & $\begin{array}{c}0.020^{*} \\
(0.001)\end{array}$ & $\begin{array}{c}0.020^{*} \\
(0.001)\end{array}$ \\
\hline Male & $\begin{array}{c}0.582^{*} \\
(0.022)\end{array}$ & $\begin{array}{c}0.796^{*} \\
(0.023)\end{array}$ & $\begin{array}{c}0.787^{*} \\
(0.024)\end{array}$ \\
\hline Protestant & $\begin{array}{c}0.353^{*} \\
(0.025)\end{array}$ & $\begin{array}{c}0.282^{*} \\
(0.025)\end{array}$ & $\begin{array}{c}0.263^{*} \\
(0.025)\end{array}$ \\
\hline Muslim & $\begin{array}{c}1.753^{*} \\
(0.140)\end{array}$ & $\begin{array}{c}1.367^{*} \\
(0.142)\end{array}$ & $\begin{array}{c}0.818^{*} \\
(0.155)\end{array}$ \\
\hline Jewish & $\begin{array}{l}-0.902^{*} \\
(0.101)\end{array}$ & $\begin{array}{c}-0.666^{*} \\
(0.105)\end{array}$ & $\begin{array}{c}-0.757^{*} \\
(0.106)\end{array}$ \\
\hline Hindu/Sikh & $\begin{array}{c}0.135 \\
(0.181)\end{array}$ & $\begin{array}{c}0.092 \\
(0.187)\end{array}$ & $\begin{array}{c}-0.491^{*} \\
(0.199)\end{array}$ \\
\hline Other Religion & $\begin{array}{l}-0.358^{*} \\
(0.061)\end{array}$ & $\begin{array}{l}-0.129^{*} \\
(0.063)\end{array}$ & $\begin{array}{c}-0.199^{*} \\
(0.063)\end{array}$ \\
\hline No Religion & $\begin{array}{l}-1.046^{*} \\
(0.035)\end{array}$ & $\begin{array}{l}-0.006 \\
(0.040)\end{array}$ & $\begin{array}{c}-0.050^{*} \\
(0.041)\end{array}$ \\
\hline Religiosity & & $\begin{array}{c}0.829^{*} \\
(0.015)\end{array}$ & $\begin{array}{c}0.827^{*} \\
(0.015)\end{array}$ \\
\hline Middle East & & & $\begin{array}{c}0.960^{*} \\
(0.185)\end{array}$ \\
\hline South Asia & & & $\begin{array}{c}1.142^{*} \\
(0.198)\end{array}$ \\
\hline Africa & & & $\begin{array}{c}0.835^{*} \\
(0.168)\end{array}$ \\
\hline East Asia & & & $\begin{array}{c}1.210^{*} \\
(0.105)\end{array}$ \\
\hline Americas + & & & $\begin{array}{c}0.326^{*} \\
(0.074)\end{array}$ \\
\hline Europe & & & $\begin{array}{c}0.477^{*} \\
(0.041)\end{array}$ \\
\hline $\begin{array}{l}\text { cut1 } \\
\text { _cons }\end{array}$ & $\begin{array}{c}1.884^{*} \\
(0.049)\end{array}$ & $\begin{array}{c}3.186^{*} \\
(0.057)\end{array}$ & $\begin{array}{r}3.207^{*} \\
(0.058)\end{array}$ \\
\hline $\begin{array}{l}\text { cut2 } \\
\text { _cons }\end{array}$ & $\begin{array}{c}3.351^{*} \\
(0.052)\end{array}$ & $\begin{array}{c}4.778^{*} \\
(0.061)\end{array}$ & $\begin{array}{c}4.812^{*} \\
(0.061)\end{array}$ \\
\hline N & 35948 & 35948 & 35948 \\
\hline pseudo $R^{2}$ & 0.064 & 0.118 & 0.123 \\
\hline
\end{tabular}

Standard errors in parentheses.

* $p<0.05$

Source: Ipsos 2011. 
The introduction of country of birth variables improves somewhat the fit of the model ( $\left.\mathrm{LR} \chi^{2}=325\right)$. More important for present purposes, however, are three results. First, immigrants, no matter their region of origin, are less supportive of gay rights than are native-born Canadians. All else equal, 65 percent of native-born Canadians support same-sex marriage and just under 10 percent oppose all forms of recognition. For immigrants, the comparable figures are 52 percent and 16 percent, respectively.

Second, however, region of origin plays a significant role in this equation. Immigrants from the Middle East, South Asia, Africa, and East Asia are substantially more likely to oppose same-sex marriage rights than are immigrants from American and European countries. Holding all other variables constant at their mean level, 54 percent of immigrants from European countries support same-sex marriage, but only 42 percent of immigrants from the Middle East and 37 percent of immigrants from South Asia express this view.

Third, and most important, notice by following the coefficient for Muslims across all three blocs of the model that controlling for region of origin reduces the distinctiveness of opinions among Muslims. It reduces the size of the gap between Muslims and non-Muslims by about 10 percentage points, even allowing for the higher levels of religiosity among Muslims. Country of origin closes fully a quarter of the gap between Muslims and other Canadians in support for same-sex marriage, and a third of the gap in opposition to all forms of recognition. Controlling simultaneously for religiosity does even more to reduce this gap. If Muslims were as religious as other Canadians, and if they tended to be born from the same regions of the world, then these estimate suggest that the distinctiveness of their opinions about same-sex marriage would be reduced from a 43 point spread to an 18 point spread in the case of support for same-sex marriage, and from a 34 point spread to a 9 point spread in the case of opposition to all forms of recognition. Accounting for level of religiosity and country of origin reduces by nearly 60 percent the overall differences between Muslims and nonMuslims across all three categories of opinion about same-sex marriage.

Muslims differ from other Canadians, however, not only in their immigration status and country of origin, but also in the recency of their arrival to Canada. Table 5 examines the impact among immigrants of exposure to the Canadian context. The first bloc of the model includes covariates for length of residence in Canada and for length of residence squared. In this model, the coefficients for region of origin represent the effects of each region, compared to native-born respondents, when length of exposure to the country is at its lowest possible value (o), which corresponds to immigrants 
that have been in the country for less than ten years. The coefficient for Years in Canada, as well as Years in Canada squared, capture the effect of exposure for each additional decade of an immigrant's residence in the country, on the approximately accurate assumption that the effect is constant across all categories of immigrants, regardless of their religion or region of origin.

Table 5 Length of Residence in Canada as a Predictor of Opinions about Same- Sex Relationships

\begin{tabular}{|c|c|c|c|c|}
\hline & \multicolumn{2}{|c|}{ Bloc 1} & \multicolumn{2}{|c|}{ Bloc 2} \\
\hline \multicolumn{5}{|l|}{ Gay Marriage } \\
\hline Age & $0.022^{*}$ & $(0.001)$ & $0.020^{*}$ & $(0.001)$ \\
\hline Male & $0.785^{*}$ & $(0.024)$ & $0.820^{*}$ & $(0.024)$ \\
\hline Protestant & $0.265^{*}$ & $(0.025)$ & $0.279^{*}$ & $(0.026)$ \\
\hline Muslim & $0.716^{*}$ & $(0.156)$ & $2.481^{*}$ & $(0.581)$ \\
\hline Jewish & $-0.752^{*}$ & $(0.106)$ & $-0.641^{*}$ & $(0.107)$ \\
\hline Hindu/Sikh & $-0.596^{*}$ & $(0.201)$ & $-0.612^{*}$ & $(0.203)$ \\
\hline Other Religion & $-0.204^{*}$ & $(0.063)$ & $-0.211^{*}$ & $(0.064)$ \\
\hline No Religion & -0.048 & $(0.041)$ & -0.049 & $(0.041)$ \\
\hline Religiosity & $0.826^{*}$ & $(0.015)$ & $0.815^{*}$ & $(0.015)$ \\
\hline MiddleEast & $1.497^{*}$ & $(0.194)$ & $1.822^{*}$ & $(0.214)$ \\
\hline SouthAsia & $1.653^{*}$ & $(0.207)$ & $1.995^{*}$ & $(0.227)$ \\
\hline Africa & $1.430^{*}$ & $(0.182)$ & $1.762^{*}$ & $(0.205)$ \\
\hline EastAsia & $1.810^{*}$ & $(0.127)$ & $2.092^{*}$ & $(0.158)$ \\
\hline Americas & $1.081^{*}$ & $(0.111)$ & $1.303^{*}$ & $(0.140)$ \\
\hline Europe & $1.357^{*}$ & $(0.101)$ & $1.522^{*}$ & (0.128) \\
\hline Years in Canada & $-0.436^{*}$ & $(0.064)$ & $-0.458^{*}$ & $(0.064)$ \\
\hline Years in Canada ${ }^{2}$ & $0.045^{*}$ & $(0.010)$ & $0.046^{*}$ & $(0.010)$ \\
\hline Education & & & $-0.126^{*}$ & $(0.007)$ \\
\hline Muslim.Immigrant & & & $-2.191^{*}$ & $(0.791)$ \\
\hline Muslim.Education & & & -0.275 & (0.146) \\
\hline Immigrant.Education & & & -0.013 & $(0.020)$ \\
\hline $\begin{array}{l}\text { Muslim.Immigrant. } \\
\text { Education }\end{array}$ & & & 0.285 & $(0.187)$ \\
\hline \multicolumn{5}{|l|}{ cut1 } \\
\hline _cons & $3.297^{*}$ & $(0.059)$ & $2.828^{*}$ & $(0.065)$ \\
\hline \multicolumn{5}{|l|}{ cut2 } \\
\hline _cons & $4.905^{*}$ & $(0.061)$ & $4.449^{*}$ & $(0.067)$ \\
\hline
\end{tabular}




\begin{tabular}{lccc}
\hline & Bloc 1 & Bloc 2 \\
\hline $\mathrm{N}$ & 35948 & 35948 & \\
pseudo $\mathrm{R}^{2}$ & 0.124 & 0.130
\end{tabular}

Standard errors in parentheses.

* $p<0.05$

Source: Ipsos 2011.

Figure 7 summarizes the impact of length of residence in Canada on immigrants' opinions about same-sex relationships. The x-axis corresponds to length of residence in Canada, and the y-axis represents the predicted level of support for same-sex marriage among immigrants, when all other variables in Bloc 1 of the model are held constant at their mean level for immigrants. The size of the points represents the proportion of Muslim immigrants (circles) and all immigrants (squares) at each category of length of residence. The three horizontal lines, beginning from bottom to top, represent the average level of support for same-sex marriage among Muslims, among immigrants, and among the Canadian population as a whole.

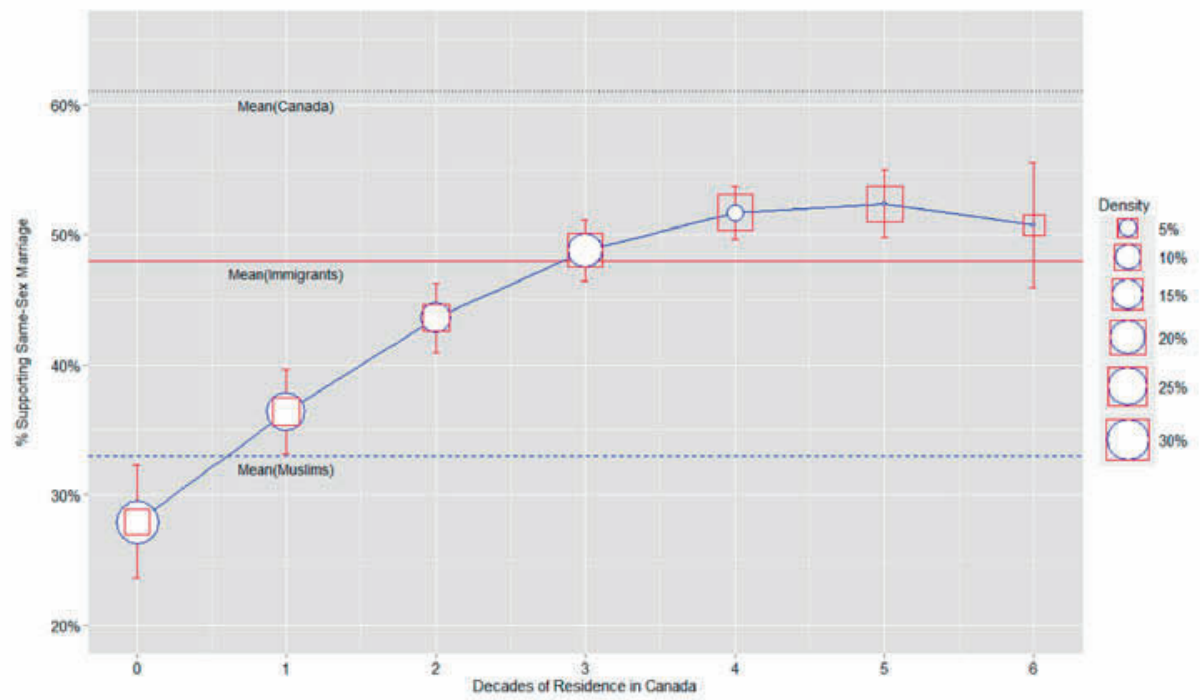

Figure 7 Supportfor Same-Sex Marriage Among Immigrants, by Length of Residence in Canada

Source: Ipsos 2011.

Two key findings emerge from this Figure. First, immigrants with high levels of exposure to the Canadian context are more favorably disposed 
toward same-sex marriage, and the effect of exposure is non-linear: a one unit increase in level of exposure has its greatest effect at lower levels of exposure, and virtually no effect at higher levels. The effect of each additional year of exposure wanes over time.

Second, notice by looking at the size of the points the uneven distribution of Muslims vis-a-vis other immigrants across categories of exposure. Compared to other immigrants, Muslims are disproportionately concentrated in the lower values of length of residence in Canada, where levels of support for same-sex marriage are very low. They are virtually non-existent in the highest categories of length of residence in Canada, where levels of support for same-sex marriage are considerably higher. Indeed, 6o percent of Muslim immigrants are concentrated in the first two categories of length of exposure, and 95 percent are concentrated in the first four categories. By comparison, just 21 and 51 percent of non-Muslim immigrants are within these categories. This difference contributes somewhat to the higher levels of opposition to same-sex marriage among Muslim immigrants. Controlling for length of residence in Canada by setting the values of this variables constant at its mean level for all immigrants reduces the opinion gap between Muslim and non-Muslim immigrants by about 6 percentage points, even allowing for the higher levels of religiosity among Muslims and their greater likelihood of having arrived from Africa, the Middle East, and South Asia.

Although taking account of appropriate statistical controls reduces the magnitude of the differences between Muslims and non-Muslims, Muslims remain distinctive from other groups of Canadians, even when level of religiosity, region of origin, and length of residence in Canada are all taken into account. It is helpful to figure out which Muslims are driving this difference. Bloc 2 of Table 5 suggests important heterogeneity within the Muslim-Canadian community. This bloc of the model introduces level of education into the equation, as well as a battery of interaction terms that allow for the possibility that the effects of education may vary between native-born and foreign-born Canadians, between Muslims and nonMuslims, and between native-born and foreign-born Muslims.

Figure 8 plots the predicted levels of support and opposition to same-sex relationships for different groups of Canadians at different levels of formal education, when all other variables are held constant at their mean level. ${ }^{1}$ The values on the $\mathrm{x}$-axis represent level of education, and the positive and negative values on the $y$-axis represent the predicted probabilities of supporting same-sex marriage and opposing all forms of recognition, respectively. The white lines represent the predicted levels of support and opposition for Canadians as a whole, and the black lines represent predicted levels for 
Muslims. These shaded regions corresponds to the 95 percent confidence intervals of the estimates. The left-hand panel compares across educational categories foreign-born Muslims to Canadians as a whole, and the right-hand panel compares native-born Muslims to Canadians as a whole.

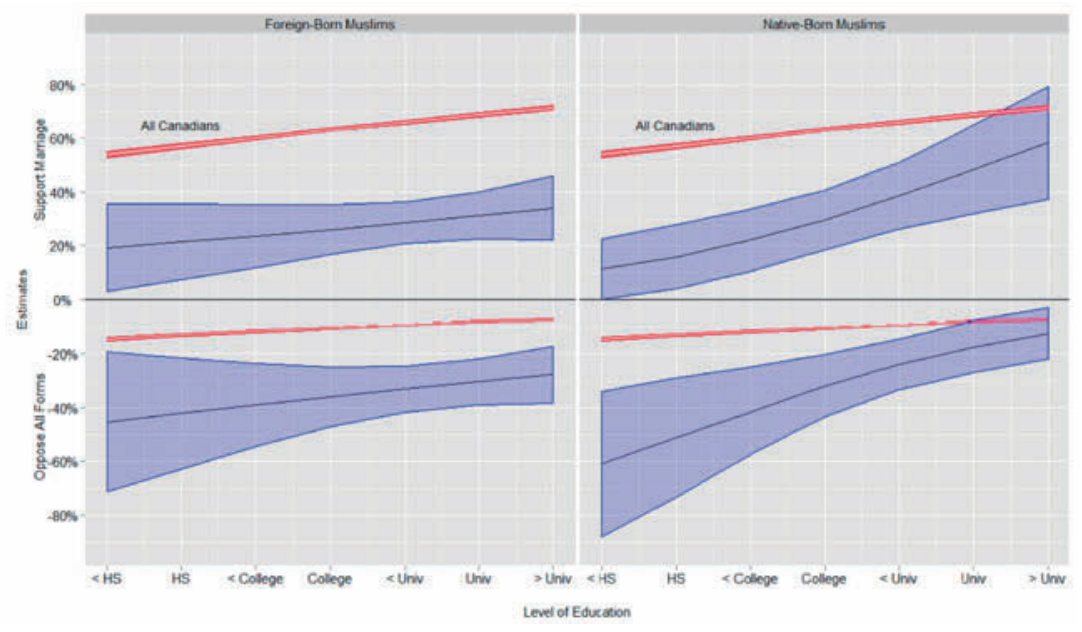

Figure 8 Support for Same-Sex Marriage Among Muslims, by Level of Education Sources: Ipsos 2011.

The Figure summarizes two key findings. First, as expected, a higher level of formal education is associated with increased support for same-sex relationships. This pattern applies among all Canadians-including immigrants-and it applies among native-born and foreign-born Muslims. Indeed, the inclusion of education as a predictor of opinions about same-sex relationships generates a notable improvement in the fit of the model.

Second, however, notice that the effect of education on opinions about same-sex marriage is more pronounced among native-born Muslims than among foreign-born Muslims. As level of education increases, the size of the gap between foreign-born Muslims and all Canadians remains unchanged, but it closes quite considerably between native-born Muslims and all Canadians. The difference between native-born and foreign-born Muslims in the rate of change across categories of education is substantively as well as statistically significant.

Intriguingly, these patterns are not the result of different levels of religiosity. There is no empirical relationship among Muslims between level of formal education and level of religiosity. These two variables are altogether unconnected to each other among Muslims $(b=.02, p=.599)$, despite their 
rather strong inverse relationship in the population as a whole $(b=-.06$, $\mathrm{p}=.000)$.

\section{Conclusion}

Canadians Muslims express less support for same-sex relationships than do members of other major religious groups in Canada. But there are reasons to question the extent to which Islam as a religion should be singled out as the cause of these opinions. Public opinion about homosexuality has undergone a drastic transformation in Canada over the past three decades; a transformation that most Muslims, unlike most other Canadians, were not in the country to experience. Indeed, the opinion environments in the regions of the world from which Canadian Muslims tend to emigrate are invariably hostile toward homosexuality, regardless of the proportion of Muslims in those countries.

The results of the analyses uncover some support for the religiosity hypothesis. Religiosity in general is associated with higher levels of opposition to same-sex relationships, and Muslims turn out to be more religious than other Canadians. There appears to be nothing peculiar, however, about Islamic religiosity. There is no evidence in these data that a commitment to Islam generates more negative opinions about same-sex relationships than does a commitment to other, more mainstream religions in Canada, including Protestantism.

The results are similarly mixed for the foreign socialization hypothesis. Certainly, the greater likelihood of foreign-birth among Muslims, combined with their disproportionate representation among immigrants from African, Middle-Eastern and South Asian countries, goes some way toward explaining their distinctive opinions about same-sex marriage. Opinions about same-sex relationships are particularly distinctive among Muslim immigrants, and they are more distinctive among Muslim immigrants that have arrived to Canada relatively recently than they are among the very small number of Muslim immigrants that have been in the country for a number of years. Yet, the story of opinions about same-sex marriage cannot be told without religiosity, and level of religiosity appears to decline very slowly among Muslim immigrants to Canada. Moreover, the Canadian Muslims that stand out the most for their opinions about same-sex relationships are native-born Muslims with low levels of formal education. To what extent the effect of education is a product of self-selection or of socialization-or, indeed, of something else-is a question that is beyond the reach of the 
tools employed in this analysis. Nonetheless, it suggests that although the distinctiveness of Muslim-Canadian opinions is particularly pronounced among foreign-born Muslims, it is not confined to them.

These results point to important sources of heterogeneity with the Muslim Canadian community. Muslims are not a single monolithic group. Indeed, native-born Muslims with a university education are far less distinctive from other Canadians with a university education than native-born Muslims with a very low level of education are from other similarly educated Canadians. There appears to be something about exposure to formal education in Canada-as opposed to exposure to formal education in the countries from which Muslims emigrate-that is associated with a marked liberalization of Muslim-Canadian opinions about same-sex marriage. This effect, moreover, does not operate through religiosity. A higher level of education is not associated among Muslims with lower levels of religiosity.

To the extent that the results uncovered here are generalizable to other contexts, and to the extent that they stand up to replication using new data, the substantive conclusions may well be important for the broader debate about Muslim immigration in liberal societies. Muslim-Canadian opinion about same-sex relationships is not, first and foremost, a story about Islam. Rather, it is primarily a story about religiosity and of immigrant integration more generally. To be sure, opposition to all forms of legal recognition of same-sex marriage is more common among Muslim-Canadians than among other Canadians. However, within this Muslim-Canadian community, this opposition is confined to those who were born in countries where opposition to gay rights is common- regardless of their level of formal education-and to those who were born in Canada but have no exposure to post-secondary education. Canadian-born Muslims with a university degree are no more opposed than other university-educated Canadians to the legal recognition of same-sex relationships. It seems that the school is more important than the Mosque as a source of Muslim-Canadian opinions about same-sex relationships.

More generally, the findings in this paper challenge the analytical utility of following the convention in political discourse that treats Muslims as a distinctive category whose aggregate properties are then associated with the lone characteristic-Islam-that defines the boundary for this group as a whole. Religiosity in general, rather than Islamic religiosity in particular, is associated with heightened opposition to same-sex marriage. Being born and raised in regions of the world where opposition to homosexuality is common is, for Muslims and non-Muslims alike, associated with opposition to same-sex relationships among recent immigrants, but the effect wanes 
over time with exposure to the new society. And the effect of exposure to higher levels of education in the new society is powerfully and consistently associated with more liberal attitudes toward same-sex marriage; however, this association applies for second-generation immigrants more generally, rather than for Muslims in particular. The rapid cultural transformation in Canada around the issue of sexual orientation progressed, in less than two decades, from a point where sexual minorities were ostracized in public and private life to a point where the acceptance of sexual diversity is considered by many as a defining element of the country's political culture and, indeed, as an "index of civilization" (Scott, 2009). This new political climate is often leveraged in Canada, as it is elsewhere, against Muslims. The results in this paper, however, suggest that there is nothing distinctive about Canadian Muslims when public opinion is examined from the vantage point of individual-level predictors of attitudes toward same-sex marriage.

\section{Note}

1. The region of birth variables for foreign-born Muslims are held constant at their aver- age level among all immigrants, thus setting to 1 , in effect, the constituent variable "immigrant" in the interaction terms for Muslim.Immigrant, Immigrant.Education, and Muslim.Immigrant.Education.

\section{References}

Abramson, P. and Inglehart, R. (1994). Education, security, and postmaterialism: A comment on Dutch and Taylor's postmaterialism and the economic condition. American Journal of Political Science, $38(3): 797-814$.

Adamczyk, A. and Pitt, C. (2009). Shaping attitudes about homosexuality: The role of religion and cultural context. Social Science Research, 38(2):338-351.

Adida, C., Laitin, D. D., and Valfort, M.-A. (2010). Identifying barriers to Muslim integration in France. Proceedings of the National Academic of Sciences, $107\left(5^{2}\right): 384-390$.

Akkerman, T. (2005). Anti-immigration parties and the Defence of liberal values: The exceptional case of the List Pim Fortuyn. Journal of Political Ideologies, 10(3):337-354.

Akkerman, T. (2010). Women and children first! Anti-immigration parties and gender in Norway and the Netherlands. Patterns of Prejudice, 41(2):197-214.

Betz, H.-G. and Meret, S. (2009). Revisiting Lepanto: The political mobilization against Islam in contemporary Western Europe. Patterns of Prejudice, 43(3):313-334.

Bevelander, P. and Otterbeck, J. (2010). Young people's attitudes towards Muslims in Sweden. Ethnic and Racial Studies, 33(3):404-425.

Bleich, E. (2003). Race Politics in Britain and France: Ideas and Policymaking since the 196os. New York, NY: Cambridge University Press. 
Bleich, E. (2009). Where do Muslims stand on ethno-racial hierarchies in Britain and France? Evidence from public opinion surveys, 1988-2008. Patterns of Prejudice, 43(3):379-400.

Boswell, J. (1980). Christianity, Social Tolerance and Homosexuality: Gay People in Western Europe from the Beginning of the Christian Era to the Fourteenth Century. Chicago, IL: University of Chicago Press.

Bouchard, G. and Taylor, C. (2008). Building the Future: A Time for Reconciliation. Report of the Commission de Consultation sur les Pratiques D'Accommodement Reliees aux Differencs Culturelles. Quebec, PQ: Government of Quebec.

Chang, L. and Krosnick, J. A. (2009). National surveys via rdd telephone interviewing versus the internet: Comparing sample representativeness and response quality. Public Opinion Quarterly, 73(4):641-678.

Chui, T., Tran, K., and Maheux, H. (2007). Immigration in Canada: A portrait of the foreign-born population, 2006 census. Statistics Canada, Catalogue no.97-557:1-37.

Connor, P. (2010). Contexts of immigrant receptivity and immigrant religious outcomes: the case of Muslims in Western Europe. Ethnic and Racial Studies, 33(3):376-403.

Dutch, R. and Taylor, M. (1993). Postmaterialism and the economic condition. American Journal of Political Science, 37(3):747-779.

Ehrkamp, P. (2010). The limits of multicultural tolerance? Liberal democracy and media portrayals of Muslim migrant women in Germany. Space \& Polity, 14(1):13-32.

Eliadis, P. (2007). Belonging? Diversity Recognition and Shared Citizenship in Canada, chapter Diversity and Equality: The Vital Connection, pages 547- 559. Montreal, PQ: The Institute for Research on Public Policy.

European Values Study Group and World Values Survey Association (2010). European and world values survey - microdata [computer file]. Madrid, Spain and Tilburg University, Tilberg, the Netherlands: ASEP/JDS [producer]. Cologne, Germany: ASEP/JDS and GESIS [distributor].

Fassin, E. (2010). National identities and transnational intimacies: Sexual democracy and the politics of immigration in Europe. Political Culture, 22(3):507-529.

Fekete, L. (2008). Integration, Islamophobia and Civil Rights in Europe. London, UK: Institute of Race Relations.

Fetzer, J. S. and Soper, C. J. (2003). The roots of public attitudes toward state accomodation of European Muslims' religious practices before and after September 11.Journal for the Scientific Study of Religion, 42(2):247-258.

Hekma, G. (2002). Imams and homosexuality: A post-gay debate in the Netherlands. Sexualities, $5(2): 237-248$.

Inglehart, R. (1997). Modernization and Postmodernization: Cultural, Economic, and Political Change in 43 Societies. Princeton, NJ: Princeton University Press.

Inglehart, R. and Norris, P. (2003). The true clash of civilizations. Foreign Policy, 135:62-70.

Ipsos (2006). 2006 election exit poll: microdata file [computer file]. Toronto, ON: Ipsos [producer]. Laurier Institute for the Study of Public Opinion and Policy [distributor], 2010/10/01.

Ipsos (2011). 2011 election exit poll: microdata file [computer file]. Toronto, ON: Ipsos [producer]. Laurier Institute for the Study of Public Opinion and Policy [distributor], 2012/07/o1.

Jedwab, J. (2011). Groups and intergroup relations: Canadian perceptions. Online. Accessed July 10, 2012.

Jennings, M. K. and Niemi, R. G. (1981). Generations and Politics: A Panel Study of Young Adults and their Parents. Princeton, NJ: Princeton University Press.

Leger Marketing Research (2011). A decade after September 11th 2001. Online. Accessed July 10, 2012. Little, R, J. A. (1992). Regression with missing X's: A review. Journal of the American Statistical Association, 87(420):1227-1237. 
Mepschen, P., Duyvendak, J. W., and Tonkens, E. H. (2010). Sexual politics, orientalism and multicultural citizenship in the Netherlands. Sociology, 44(5):962-979.

Municipalité de Hérouxville (2010). Normes de vie de la Municipalité de Hérouxville. Online. Accessed July 20, 2010.

Pew Research Center (2011). The future of the global Muslim population: Projections for 2010-2030. Online. Accessed February 15, 2011.

Razak, S. H. (2008). Casting Out: The Eviction of Muslims from Western Law and Politics. Toronto, ON: University of Toronto Press.

Rimmerman, C. A., Wald, Kenneth, D., and Wilcox, C. (2000). The Politics of Gay Rights. Chicago, IL: University of Chicago Press.

Scheepers, P., Gijsberts, M., and Coenders, M. (2002). Ethnic exclusionism in European countries: Public opposition to civil rights for legal migrants as a response to perceived ethnic threat. European Sociological Review, 18(1):17- 34 .

Scott, J. W. (2009). Sexularism. Ursula Hirschmann Annual Lecture on Gender and Europe. Florence, IT: European University Institute.

Semyonov, M., Raijman, R., and Gorodzeisky, A. (2006). The rise of anti-foreigner sentiment in European societies, 1988-2000. American Sociological Review, 71(3):426-449.

Shachar, A. (2000). Should Church and State be Joined at the Altar? Women's Rights and the Multicultural Dilemma. In W. Kymlicka, \& W. Norman (Eds.) Citizenship in Diverse Societies (pp. 119-136). Oxford, UK: Oxford University Press.

Shadid, W. (1991). The integration of Muslim minorities in the Netherlands. International Migration Review, 25(2):355-374.

Sniderman, P. M., Peri, P., Figueiredo, R. J. P., and Piazza, T. (2000). The Outsider: Prejudice and Politics in Italy. Princeton, NJ: Princeton University Press.

Statistics Canada (2001). 2001 Census of Canada:public use microdata file - individuals file [computer file]. Revision 2. Ottawa, ON: Statistics Canada [producer]. Data Liberation Initiative [distributor], 2006/04/26. (STC 95Moo16XCB).

Strabac, Z. and Listhaug, O. (2008). Anti-Muslim prejudice in Europe: A multilevel analysis of survey data from 30 countries. Social Science Research, 37(1):268-286.

United Nations Human Development Programme (2011). The Human Development Report 2011. New York, NY: UNDP.

Warwick, P. (1998). Disputed cause, disputed effect: The postmaterialist thesis re-examined. Public Opinion Quarterly, 62:583-609.

Weil, F. D. (1985). The variable effects of education on liberal attitudes: A comparative-historical analysis of anti-Semitism using public opinion survey data. American Sociological Review. 50:458-474.

Zolberg, A. R. and Litt Woon, L. (1999). Why Islam is like Spanish: Cultural incorporation in Europe and the United States. Politics \& Society, 27(1):5-38.

\section{About the author}

Christopher Cochrane, University of Toronto.

E-mail: christopher.cochrane@utoronto.ca. 


\section{(c) (i) (8) $\Theta$}

2013 Cochrane / Amsterdam University Press.

This is an Open Access article distributed under the terms of the Creative Commons Attribution License (http:// creativecommons.org/licenses/by/2.o), which permits unrestricted use, distribution, and reproduction in any medium, provided the original work is properly cited. 